\title{
Equations Adsorption Isotherms for Biuret on Soils, Paper and Cortex Plant Application of the Freundlich, Langmuir, Temkin, Elovich, Flory-Huggins, Halsey, and Harkins-Jura
}

\author{
Layla Balasem Almalike \\ Southern Technical University, Department Chemical and Petrochemical Engineering, Technical Engineering \\ College/Basra
}

*Corresponding Author: Layla Balasem Almalike, Southern Technical University, Department Chemical and Petrochemical Engineering, Technical Engineering College/Basra

\begin{abstract}
Adsorption is considered to be one of the most effective technologies widely used in global environmental protection areas. Modeling of experimental adsorption isotherm data is an essential way for predicting the mechanisms of adsorption, which will lead to an improvement in the area of adsorption science. In this paper, we employed seven isotherm models, namely: Freundlich, Langmuir, Elovich, Temkin, Harkins-Jura, Halsey, and Flory-Hugginsto correlate seven sets of experimental adsorption isotherm data, which were obtained by batch tests in laboratory. In order to determine the best fit isotherm model, the correlation coefficient $\left(R^{2}\right)$ foreach parameter was used to evaluate the data. The kinetics study for adsorption processes were found to verity the first order rate law. Thermodynamic parameters $\left(\Delta G^{\circ}, \Delta H^{\circ}\right.$ and $\left.\Delta S^{\circ}\right)$ were also calculated, indicating the endothermic processes.
\end{abstract}

Keywords: biuret, adsorption isotherm, thermodynamic parameters.

\section{INTRODUCTION}

The main advantages of adsorption process are low operating cost, easily available sorbent sources, minimization of the volume of sludge to be disposed of, recovery of the metal from the adsorbents and regeneration of the adsorbents for reuse[1] and is recognized as the most efficient, promising and widely used fundamental approach in wastewater treatment processes[2]. Adsorption is wellestablished technique for the removal of low concentrations of organic pollutants from large volumes of potable water, process effluents, wastewater, and aqueous solutions. A number of natural and synthetic adsorbents have been studied by various researchers for the removal of heavy metal ions [1]. The performance of an adsorbent can be studied by adsorption isotherm data, which can be obtained by a series of experimental tests in labs. Modeling the adsorption isotherm data is an essential way for predicting and comparing the adsorption performance, which is critical for optimization of the adsorption mechanism pathways, expression of the adsorbents capacities, and effective design of the adsorption systems [3].

Biuret $\left(\mathrm{C}_{2} \mathrm{H}_{5} \mathrm{~N}_{3} \mathrm{O}_{2}\right)$ is a known contaminant of urea fertilizers. Biuret is formed from the combining of two molecules of urea with one molecule of ammonia released during the pilling or granulation of crystalline urea when it is heated near its melting point $\left(132.8^{0} \mathrm{C}\right)$. Pure biuret contains $\left(\mathrm{g} \mathrm{kg}^{-1}\right) \mathrm{C} 233$, $\mathrm{N} \mathrm{408,} \mathrm{O} \mathrm{300,} \mathrm{and} \mathrm{H} \mathrm{49}$. It has been shown that biuret is both stimulatory and inhibitory to plant growth. In agriculture, high concentrations of pure biuret or biuret in urea fertilizer can be toxic to crops whether applied to soil or foliage. Biuret might stimulate growth at low concentration through acting as a plant growth regulator and/or soil microbial activity regulator, at higher concentrations as a slow release $\mathrm{N}$ fertilizer and be inhibitory and ultimately toxic at even higher concentrations. However, little information is available on the mechanisms of stimulation of tree growth by biuret. We hypothesized that stimulation by biuret of tree growth could be a direct metabolically regulated plant response or the results of enhancing soil nutrients, especially $\mathrm{N}$ availability through microbially mediated soil processes, or both. These potential properties of biuret could make it an attractive alternative $\mathrm{N}$ fertilizer to traditional $\mathrm{N}$ [4].

Soil is a heterogeneous mixture of several components, many of which are organic and inorganic compounds of varying compositions and surface activities [5]. 
Equations Adsorption Isotherms for Biuret on Soils, Paper and Cortex Plant Application of the Freundlich, Langmuir, Temkin, Elovich, Flory-Huggins, Halsey, and Harkins-Jura

The soil properties on which the biuret-exposed crop is grown are important in determining potential toxicity. Biuret is not retained in soil and is easily leached. Plants are generally less sensitive to biuret when it is applied to soils containing appreciable amounts of clay or organic matter, or of low $\mathrm{pH}$. The soil properties on which the biuret-exposed crop is grown are important in determining potential toxicity. [6].

2. SoILS

\subsection{Materials and Methods}

Fresh soil samples were taken from four soil samples, Collected from four main agricultural fields, representing a range of physico-chemical properties, and two samples represent paper of plant, and cortex of plant. Subsamples of homogenized soils were analyzed for moisture content, organic matter content, particle size distribution, texture, $\mathrm{pH}$, loss on ignition and exchangeable basic cations. The details were characterized in one of our previous articles [7]

\subsection{Adsorption Experiments}

Adsorption of the biuret from aqueous solution was determined at temperature $\left(25 \pm 1{ }^{0} \mathrm{C}\right)$ employing a standard batch equilibrium method. Anaqueous stock solution of biuret of $100 \mathrm{mgL}^{-1}$ was prepared by diluting $1 \mu 1$ in $100 \mathrm{ml}$ de-ionized water [8]. The stock and working solution were stored. Duplicate air-dried soil samples were equilibrated with different biuret concentrations $\left(5,10,15\right.$, and20 $\left.\mu \mathrm{g} \mathrm{ml}^{-1}\right)$ at the soil solution ratio 1:10. The samples plus blanks (no biuret) and control (no soil) were thermostated and placed in shaker for $0.5,1,2,3,3,4,6$ and $24 \mathrm{~h}$. The tubes were centrifuged for 20 min.at $3000 \mathrm{rpm}$. One $\mathrm{ml}$ of the clear supernatant was removed and analyzed for the biuret concentration. Biuret identification was done by UV, at wavelength $280 \mathrm{~nm}$. To study the effect of temperature, the same experiments were done at temperatures $\left(25,35,45 \pm 1^{\circ} \mathrm{C}\right)$ employing a standard batch equilibrium method [9].

\section{RESULTS AND DISCUSSION}

To have an insight into the adsorption behavior of biuret on the soils, paper and cortex plant samples, and to gain the optimal fitting of theoretical model, the experimental data from batch experiment were analyzed using Distribution Coefficient and seven parameter isotherm equations, Freundlich, Langmuir, Temkin, Elovich, Flory-Huggins, Halsey, and Harkins-Jura, in which linear regression analysis was used to evaluate whether the theoretical models have better or worse fit for the experimental data[10]. The respective parameters of these isotherm models have been enumerated in (Table1, and 2).

\subsection{Linear Adsorption Coefficient (Distribution Coefficient)}

The distribution coefficient $\left(\mathrm{K}_{\mathrm{d}}\right)$ was calculated using the equation (1) [11-12].

$\mathrm{C}_{\mathrm{s}}=\mathrm{K}_{\mathrm{d}} \cdot \mathrm{C}_{\mathrm{e}}$

The distribution coefficient $\left(\mathrm{K}_{\mathrm{d}}\right)$ was calculated by taking the ratio of adsorption concentration in soil $\left(\mathrm{C}_{\mathrm{s}}\right)$ and equilibrium concentration in solution $\left(\mathrm{C}_{\mathrm{e}}\right)$. The results were summarized in (Table 1) and Figure (1).

Table1. Adsorption distribution coefficients for biuret adsorption on soils, paper and cortex plant

\begin{tabular}{|l|c|c|c|c|c|c|}
\hline Parameters & $\mathrm{S}_{1}$ & $\mathrm{~S}_{2}$ & $\mathrm{~S}_{3}$ & $\mathrm{~S}_{4}$ & Paper & cortex \\
\hline $\mathrm{K}_{\mathrm{d}}$ & 14.446 & 12.581 & 10.905 & 21.691 & 14.666 & 32.752 \\
\hline $\mathrm{R}^{2}$ & 0.9799 & 0.9900 & 0.9438 & 0.9636 & 0.9816 & 0.9205 \\
\hline
\end{tabular}

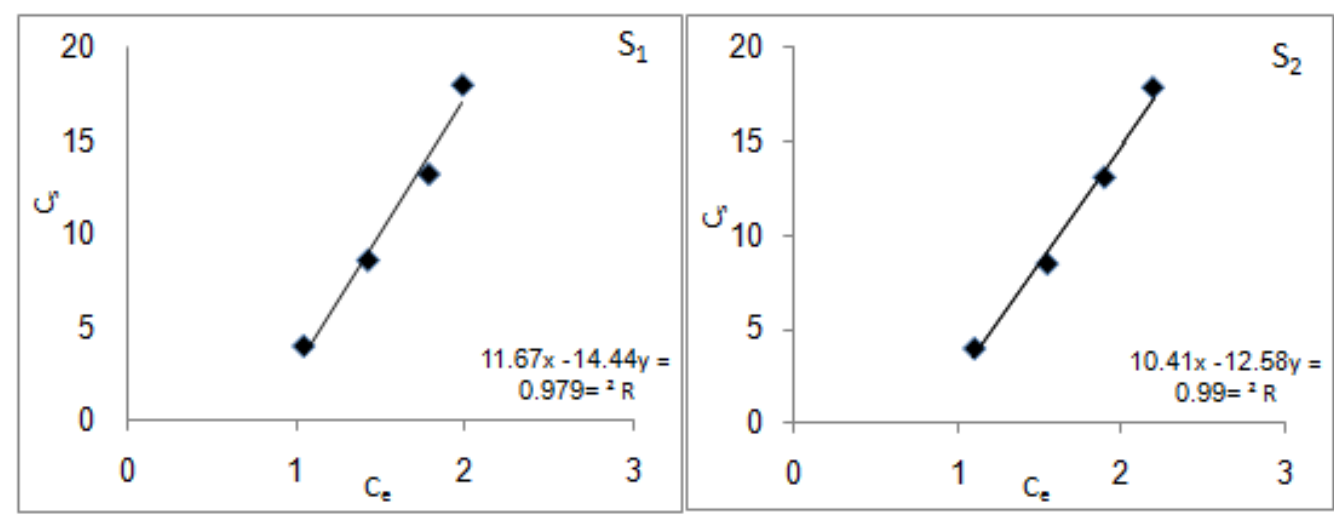


Equations Adsorption Isotherms for Biuret on Soils, Paper and Cortex Plant Application of the Freundlich, Langmuir, Temkin, Elovich, Flory-Huggins, Halsey, and Harkins-Jura
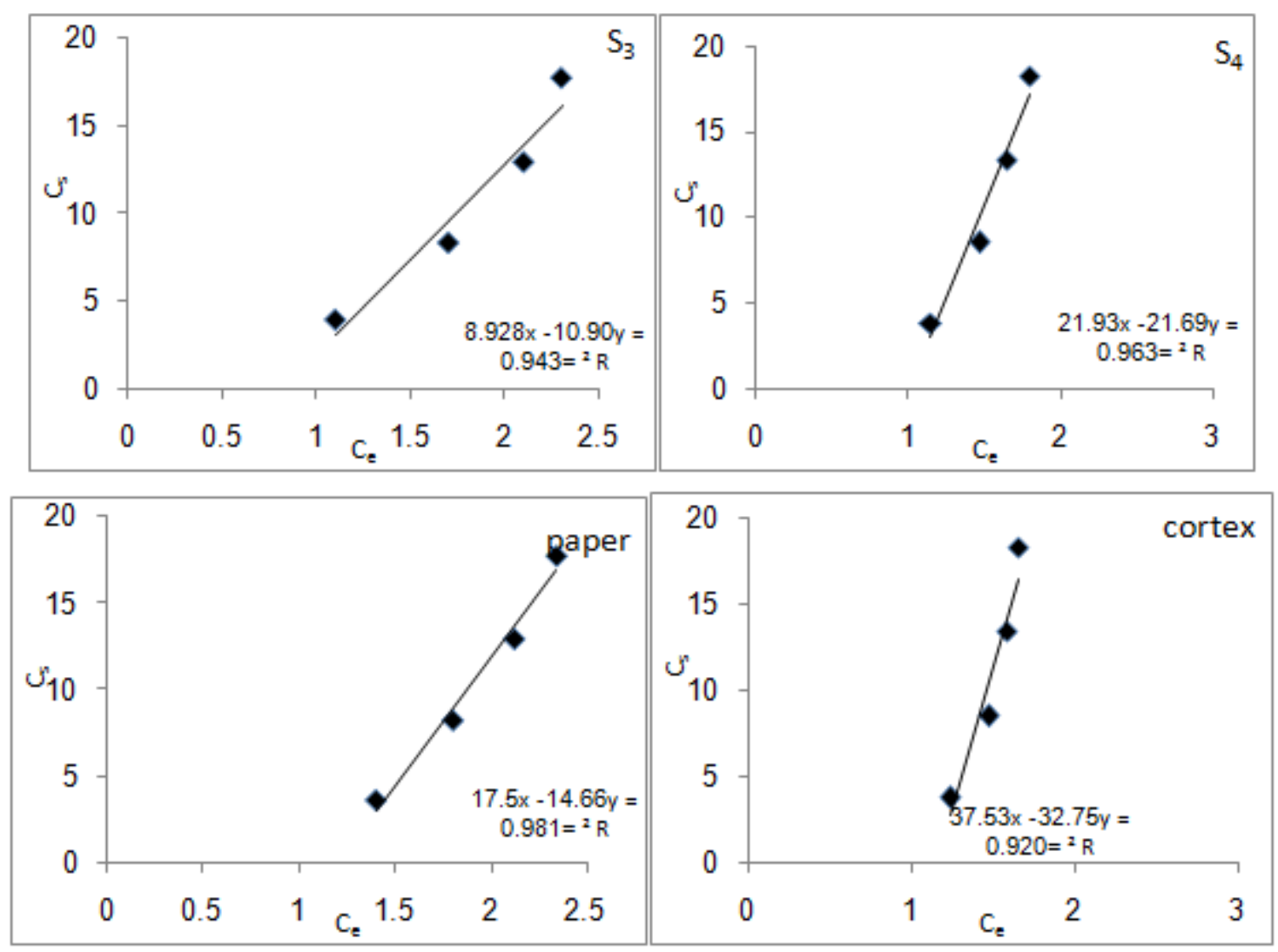

Figure1. Distribution coefficients for biuret on soils, paper of plant, and cortex of plant

\subsection{Adsorption Isotherms}

\subsubsection{Freundlich Adsorption Isotherm}

Adsorption isotherm parameters were calculated using the linearized form of Freundlich Equation (2) [13]

$\log C_{s}=\log K_{F}+1 / n \log C_{e}$

$\mathrm{C}_{\mathrm{s}}$ and $\mathrm{C}_{\mathrm{e}}$ were defined previously, $\mathrm{K}_{\mathrm{F}}$ is Freundlich adsorption coefficients, and $\mathrm{n}$ is a linearity factor, and it is also known as adsorption intensity, $1 / \mathrm{n}$ is the slope and $\log \mathrm{K}_{\mathrm{F}}$ is the intercept of the straight line resulting from the plot of $\log \mathrm{C}_{\mathrm{s}}$ versus $\log \mathrm{C}_{\mathrm{e}}$. The values of $\mathrm{K}_{\mathrm{F}}$ and $\mathrm{n}$ calculated from this regression equation showed that Freundlich adsorption model effectively describes isotherms for biuret in all cases. The results were summarized in (Table 2).

The plotting according to Freundlich isotherm model investigate the homogenous linearly of adsorbent with sorbent with $\mathrm{R}^{2}=0.9873-0.9997$ Figure (2) that is very close to survey results.

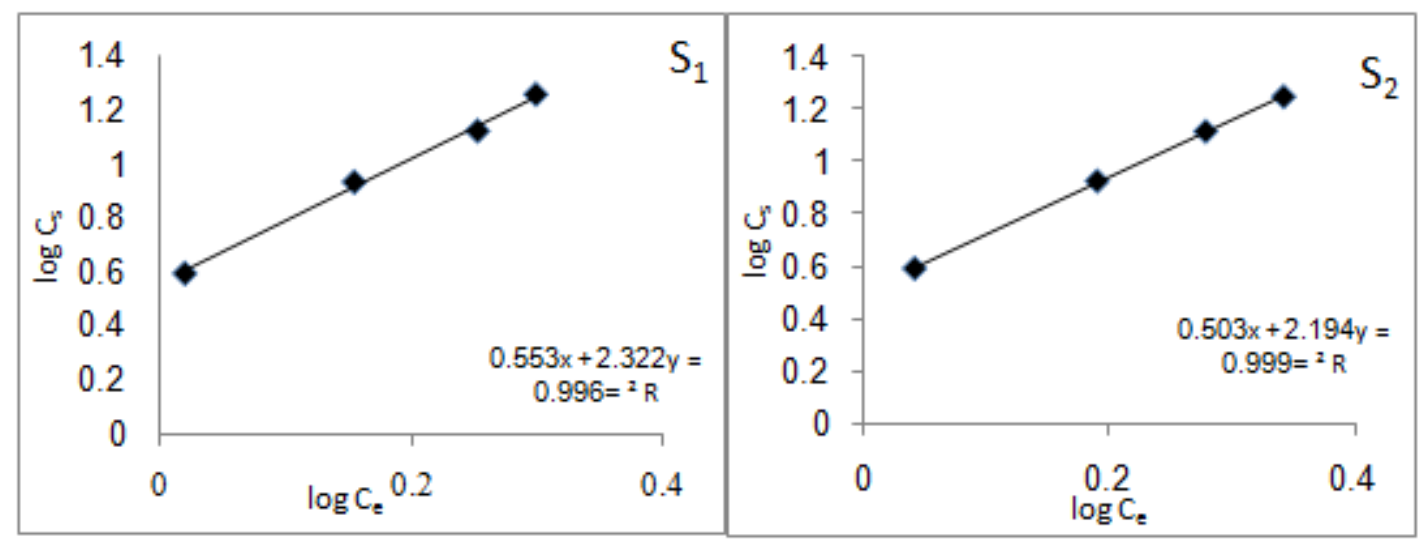


Equations Adsorption Isotherms for Biuret on Soils, Paper and Cortex Plant Application of the Freundlich, Langmuir, Temkin, Elovich, Flory-Huggins, Halsey, and Harkins-Jura
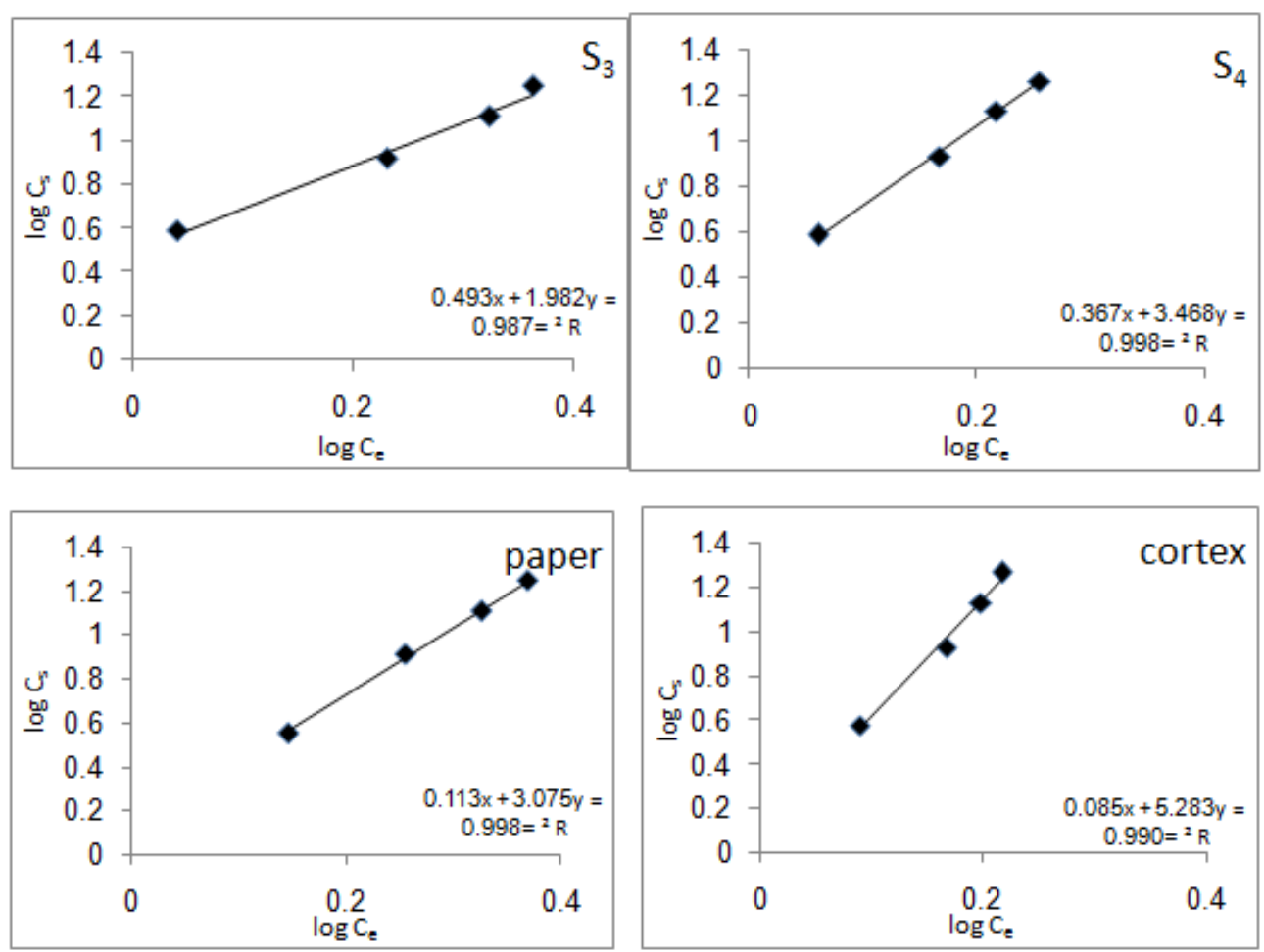

Figure2. Freundlich isotherm of biuret on soils, paper of plant, and cortex of plant

\subsubsection{Langmuir Adsorption Isotherm}

The Langmuir adsorption model is the most common model used to quantify the amount of adsorbate on an adsorbent as a function of partial pressure or concentration at a given temperature. This equation expressed by relation.

$\frac{\mathrm{C}_{\mathrm{e}}}{\mathrm{q}_{\mathrm{e}}}=\frac{1}{\mathrm{C}_{\mathrm{m}}}+\frac{1}{\mathrm{C}_{\mathrm{m}} \mathrm{K}_{\mathrm{l}} \mathrm{C}_{\mathrm{e}}}$

in this equation, $\mathrm{q}_{\mathrm{e}}\left(\mathrm{mg} . \mathrm{g}^{-1}\right)$ is the solution adsorbed by the surface and $\mathrm{q}_{\mathrm{e}}$ is equilibrium constant of adsorption and $C_{m}$ is the capacity of adsorption in saturated single layer and $C_{e}\left(m g . ~^{-1}\right)$ is solution in equilibrium state Figure(3), value $\mathrm{R}^{2}=0.9378-0.9968$, and its calculated parameters can be seen in (Table 2) [14].
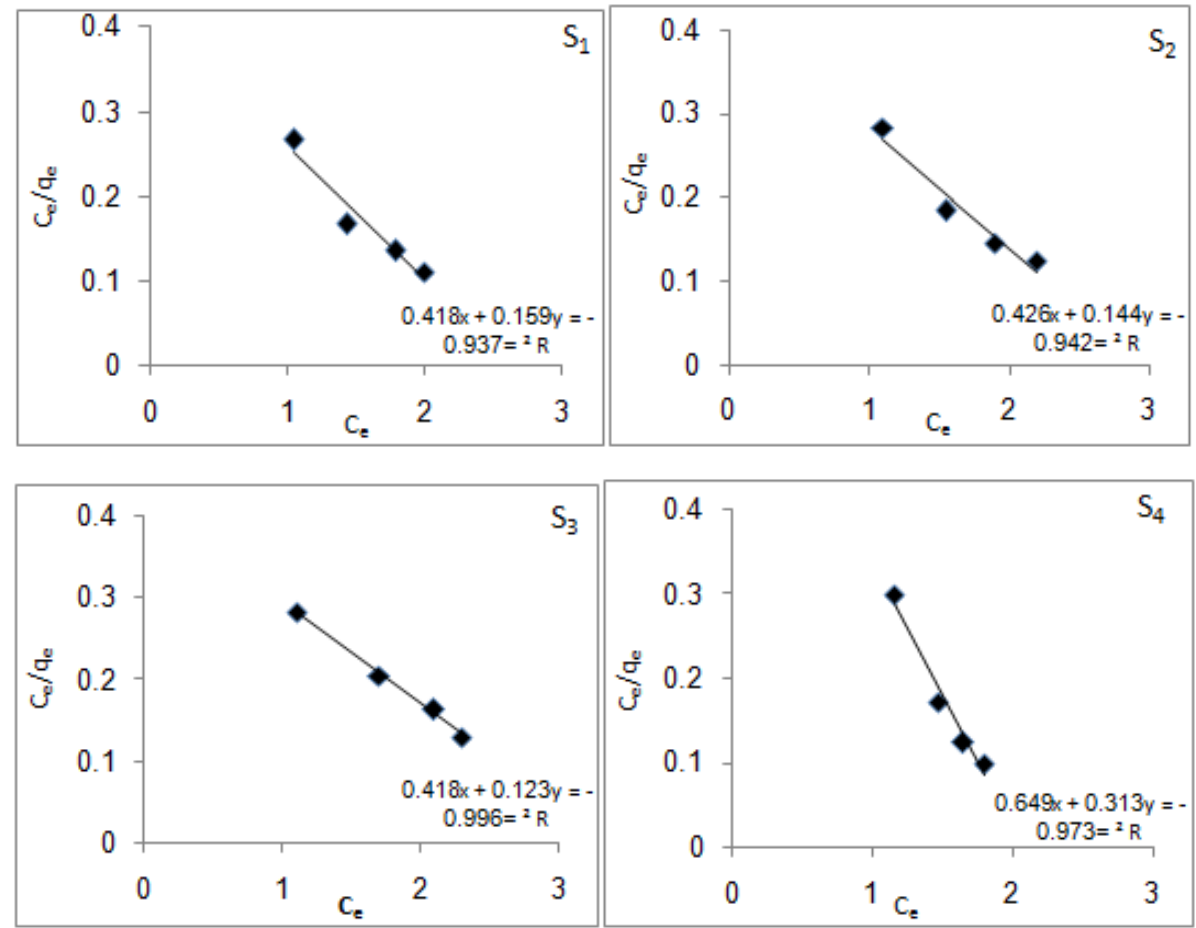

International Journal of Advanced Research in Chemical Science (IJARCS) 
Equations Adsorption Isotherms for Biuret on Soils, Paper and Cortex Plant Application of the Freundlich, Langmuir, Temkin, Elovich, Flory-Huggins, Halsey, and Harkins-Jura

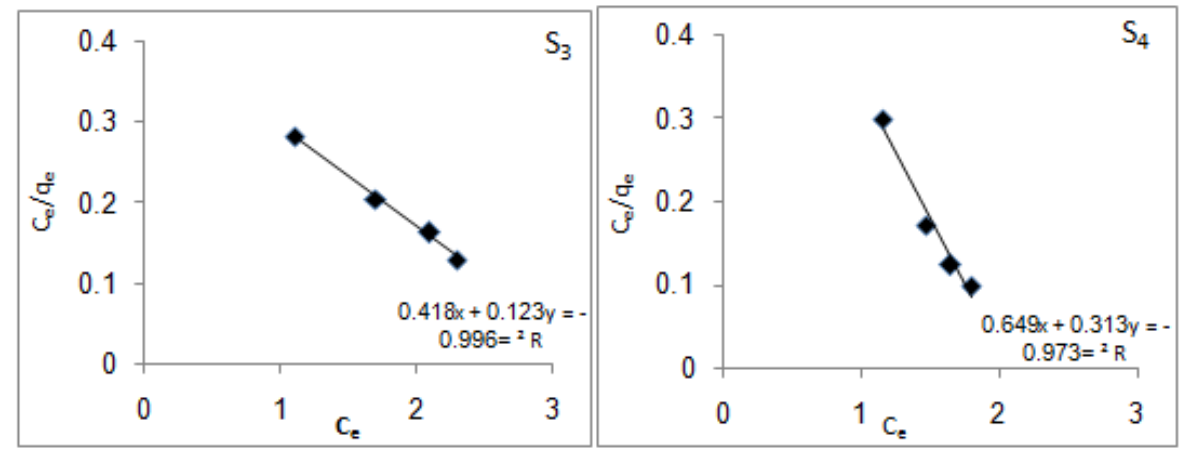

Figure3. Langmuir isotherm of biuret on soils, paper of plant, and cortex of plant

\subsubsection{Elovich Model}

The equation defining the Elovich [15] model is based on a kinetic principle assuming that the adsorption sites increase exponentially with adsorption, which implies a multilayer adsorption. It is expressed by the relation:

$\frac{\mathrm{q}_{\mathrm{e}}}{\mathrm{q}_{\mathrm{m}}}=\mathrm{K}_{\mathrm{E}} \mathrm{C}_{\mathrm{e}} \exp \left(-\frac{\mathrm{q}_{\mathrm{e}}}{\mathrm{q}_{\mathrm{m}}}\right)$

where $\mathrm{K}_{\mathrm{E}}$ is the Elovich equilibrium constant $\left(\mathrm{L} \mathrm{mg}^{-1}\right) \mathrm{q}_{\mathrm{m}}$ is the Elovich maximum adsorption capacity $\left(\mathrm{mg} \mathrm{g}^{-1}\right)$.If the adsorption obeys Elovich equation, Elovich maximum adsorption capacity [16] and Elovich constant can be calculated from the slopes and the intercepts of the plot $\ln \left(\mathrm{q}_{\mathrm{e}} / \mathrm{C}_{\mathrm{e}}\right)$ versus $\mathrm{q}_{\mathrm{e}}$ (Table 2), coefficient of determination $\left(\mathrm{R}^{2}=0.9476-0.9885\right.$ Figure (4)
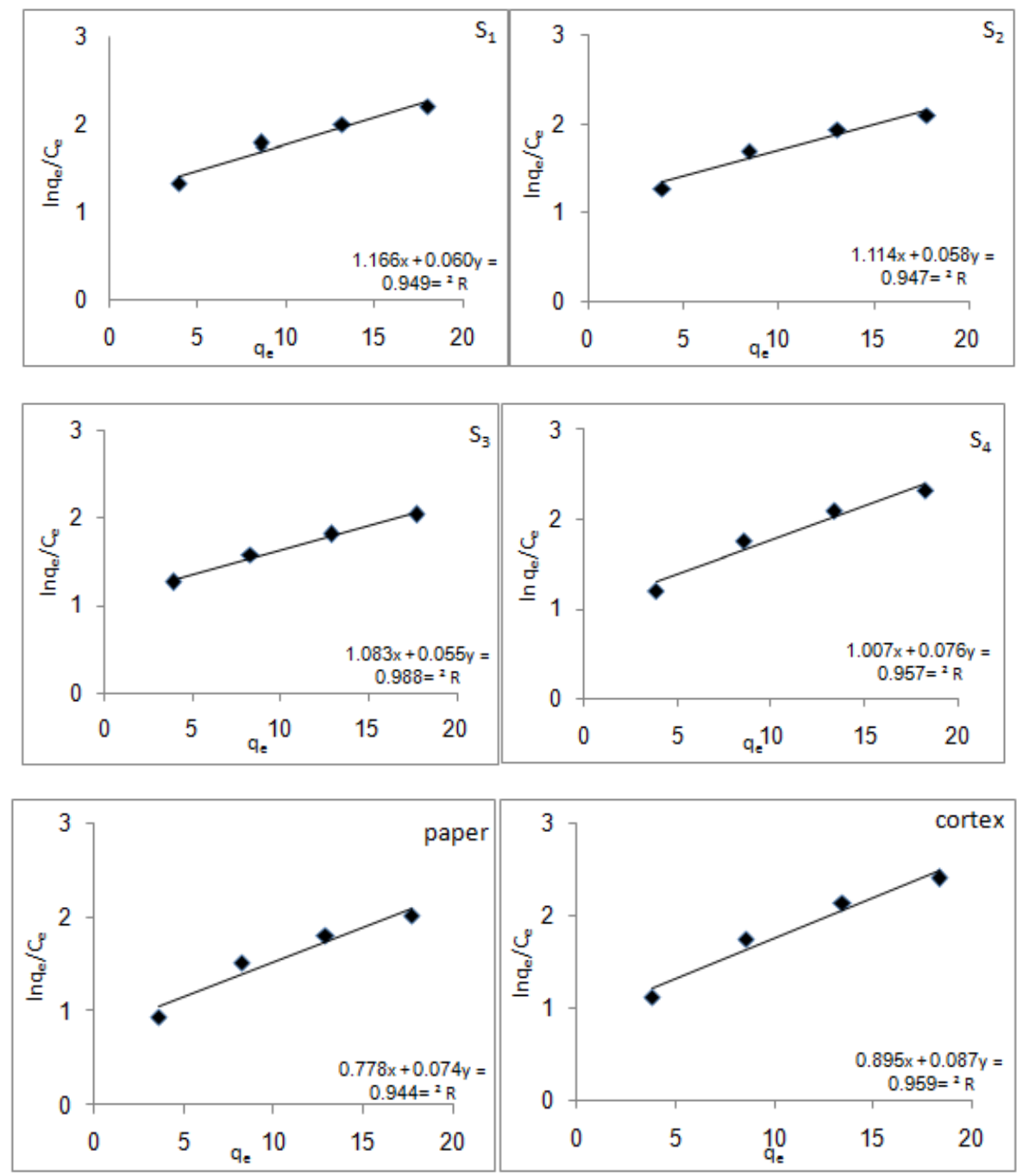

Figure4. Elovich isotherm of biuret on soils, paper of plant, and cortex of plant 
Equations Adsorption Isotherms for Biuret on Soils, Paper and Cortex Plant Application of the Freundlich, Langmuir, Temkin, Elovich, Flory-Huggins, Halsey, and Harkins-Jura

\subsubsection{Temkin Model}

The Temkin isotherm model assumes that the adsorption energy decreases linearly with the surface coverage due to adsorbent-adsorbate interactions. The linear form of Temkin isotherm model is given by the equation: [17].

$\mathrm{q}_{\mathrm{e}}=\mathrm{B} \ln \mathrm{K}_{\mathrm{T}}+\mathrm{B} \ln \mathrm{C}_{\mathrm{e}}$

Where A and B are the Temkin isotherm constant $(\mathrm{L} / \mathrm{g})$ and heat of sorption $(\mathrm{J} / \mathrm{mol})$ respectively. $\mathrm{R}$ is the gas constant $(\mathrm{J} / \mathrm{mol} / \mathrm{K}), \mathrm{b}$ is the Temkin isotherm constant linked to the energy parameter $\mathrm{B}$, as shown in equation:

$\mathrm{b}=\mathrm{RT} / \mathrm{B}$

$\mathrm{T}$ is the absolute temperature in kelvin Figure (5) and its calculated parameters are given in (Table 2)[14].

The linear form of this model is shown in Figure (5). As described in Equation (5), $\mathrm{K}_{\mathrm{T}}(1.0475-1.2588$ $\left.\mathrm{L} \cdot \mathrm{g}^{-1}\right)$ is the equilibrium binding constant, which indicates the maximum bonding energy; $\mathrm{B}_{\mathrm{T}}$ $(17.102-45.968 \mathrm{KJ} / \mathrm{mol})$ is the constant related to the heat of adsorption, these constants are calculated from the plot $\ln \mathrm{C}_{\mathrm{e}}$ and $\mathrm{q}_{\mathrm{e}}$ and tabulated in (Table 2).

However, the Temkin equation is good for predicting the equilibrium in the gas phase (when arrangement in a tightly packed structure with the same orientation is not required); conversely, the liquid-phase adsorption isotherms (complex adsorption systems) are usually not suitable to be represented [15, 18], based on the coefficient of determination $\left(\mathrm{R}^{2} 0.8953-0.9603\right.$ Figure (5)).
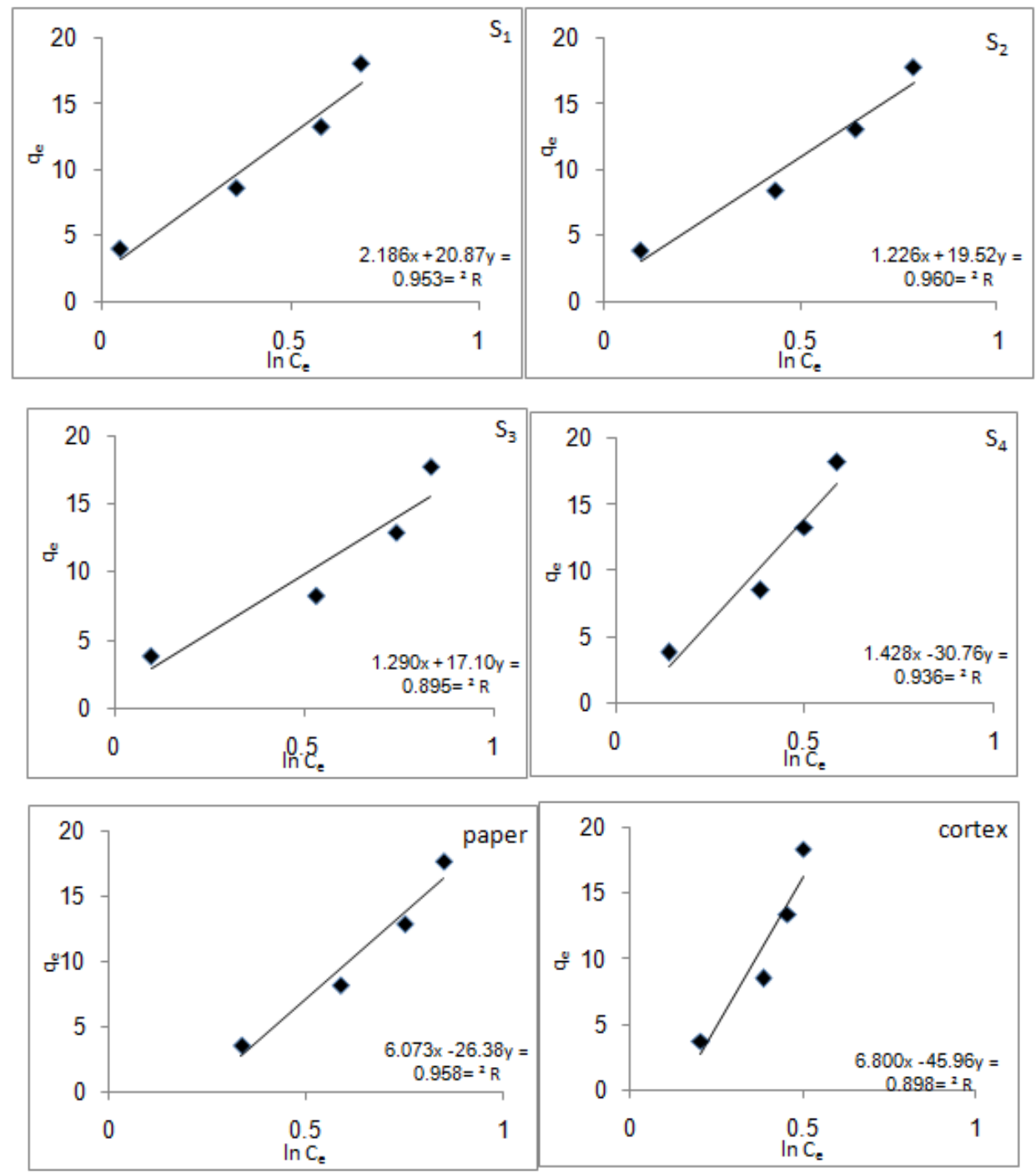

Figure5. Temkin isotherm of biuret onsoils, paper of plant, and cortex of plant 
Equations Adsorption Isotherms for Biuret on Soils, Paper and Cortex Plant Application of the Freundlich, Langmuir, Temkin, Elovich, Flory-Huggins, Halsey, and Harkins-Jura

\subsubsection{Harkins-Jura Isotherm}

This isotherm model can be discussed according to the [19] equation 7:

$\frac{1}{\mathrm{q}_{\mathrm{e}}^{2}}=\frac{\mathrm{B}}{\mathrm{A}}-\frac{1}{\mathrm{~A}} \log \mathrm{C}_{\mathrm{e}}$

By inspecting the gained Figure (6) it is obvious that correlation coefficient due to this does not give a good coincidence with experimental data [19].

The Harkins-Jura isotherm model for biuret adsorption onto soil, paper and cortex plant samples are presented inFigure 6 and the relevant isotherm parameters (Table 2) show that the values of $R^{2}$ are located inthe range of 0.8744-0.9476, which indicate a better fits to the biuret adsorption onto $\mathrm{S}_{3}$ sample. This result reveals that biuret adsorption onto paper of plant and $S_{3}$ samples are in support of the multilayer adsorption rule [20-21]. Values of constants B and A $\left(\mathrm{mg} \cdot \mathrm{g}^{-1}\right)$ of H-J isotherm model (Equation (7)) were obtained from plot $1 / \mathrm{q}_{\mathrm{e}}^{2} v s \cdot \log \mathrm{C}_{\mathrm{e}}$, Value B $0.2105-0.3505$, where value $\mathrm{A}(1.8181$ 5.0000).
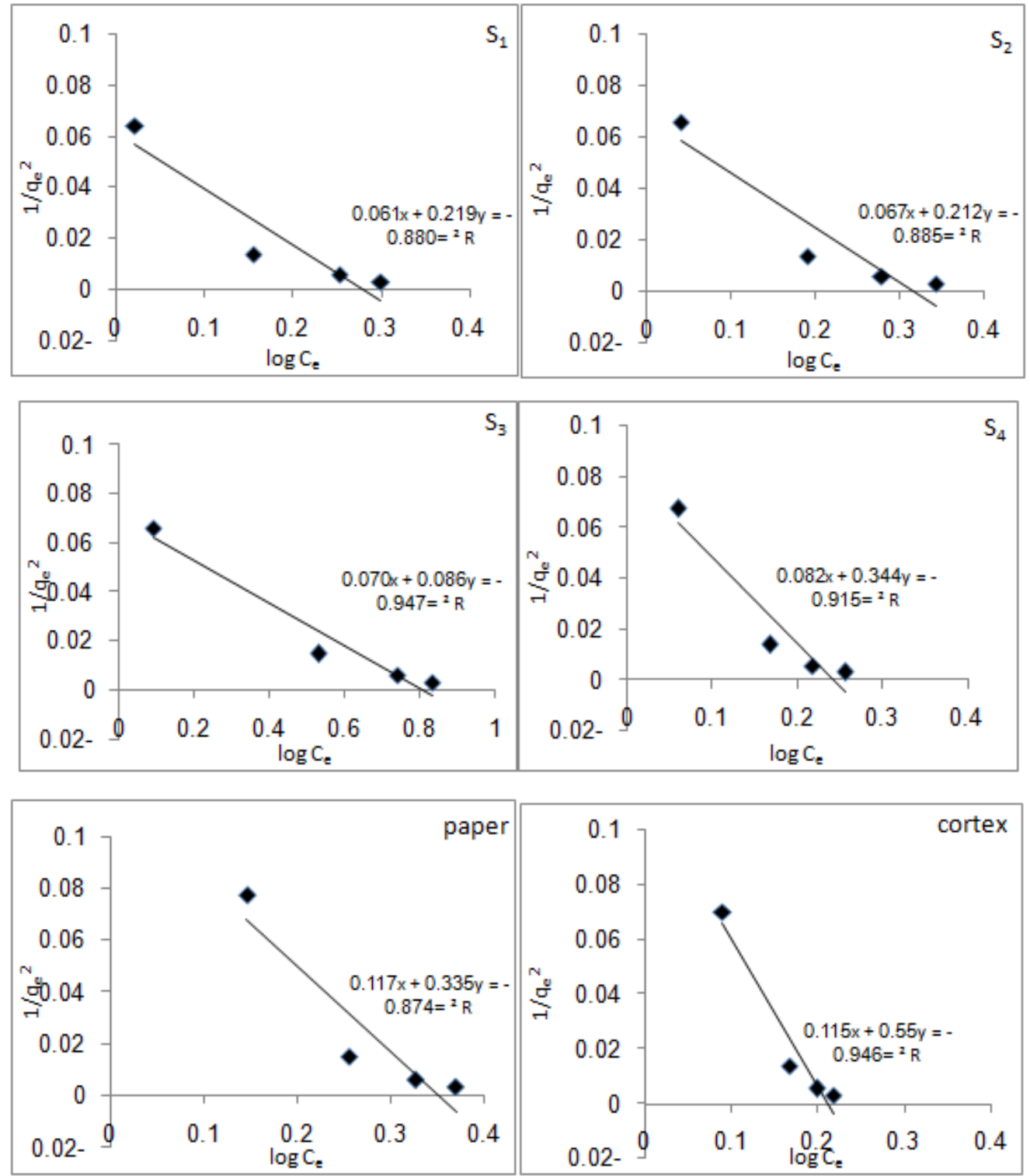

Figure6. Harkins-Jura isotherm of biuret onsoils paper of plant, and cortex of plant

\subsubsection{Halsey Adsorption Isotherm}

The Halsey adsorption isotherm can be given as [22]

$$
\ln q_{e}=\frac{1}{n} \ln K-\frac{1}{n} \ln C_{e}
$$


Equations Adsorption Isotherms for Biuret on Soils, Paper and Cortex Plant Application of the Freundlich, Langmuir, Temkin, Elovich, Flory-Huggins, Halsey, and Harkins-Jura

This equation is suitable for multilayer adsorption and the fitting of the experimental data to this equation attests the heteroporous nature of the adsorbent. The Halsey isotherm parameters are obtained from the plot of $\ln \mathrm{q}_{\mathrm{e}}$ versus $\ln \mathrm{C}_{\mathrm{e}}$ [22]. Figure (7) reflected the relatively better agreement to the adsorption data with $\mathrm{R}^{2}$, value of $R^{2}$ 0.9873-0.9997, value of $\mathrm{K}_{\mathrm{H}} 1.0378-1.7741$, and value of $\mathrm{n}$ $0.18925-0.5044$.
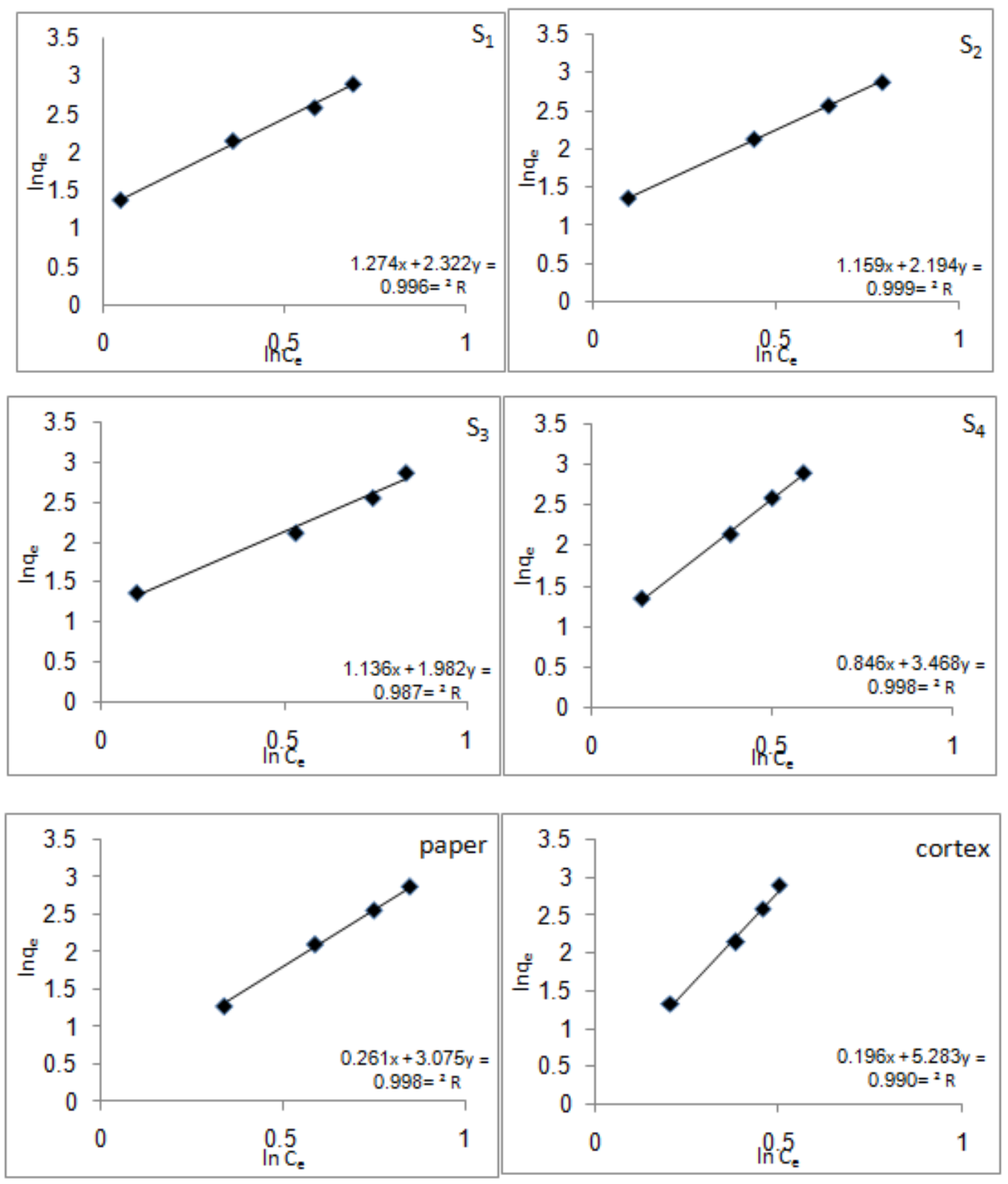

Figure7. Halsey isotherm of biuret onsoils, paper of plant, and cortex of plant

\subsubsection{Flory-Huggins Adsorption Isotherm}

The Flory-Huggins model is represented by the following equation:

$\ln \frac{\theta}{\mathrm{C} 0}=\ln \mathrm{K}_{\mathrm{FH}}+\mathrm{n} \ln (1-\theta)$

Where $\theta$ is the degree of surface coverage, $\mathrm{n}$ is the number of metal ions occupying sorption sites, $\mathrm{K}_{\mathrm{FH}}$ is the equilibrium constant of adsorption and $C_{0}$ is equilibrium biuret concentration. A plot of $\log \theta / C_{0}$ against $\log (1-\theta)$ yielding a straight line was made to confirm the model. Calculated parameters can be seen in (Table 2).

The $\theta$ in equation 10 was calculated from the relation below [23]:

$\theta=1-\frac{\mathrm{C}_{\mathrm{e}}}{\mathrm{C}_{0}}$ 
Equations Adsorption Isotherms for Biuret on Soils, Paper and Cortex Plant Application of the Freundlich, Langmuir, Temkin, Elovich, Flory-Huggins, Halsey, and Harkins-Jura
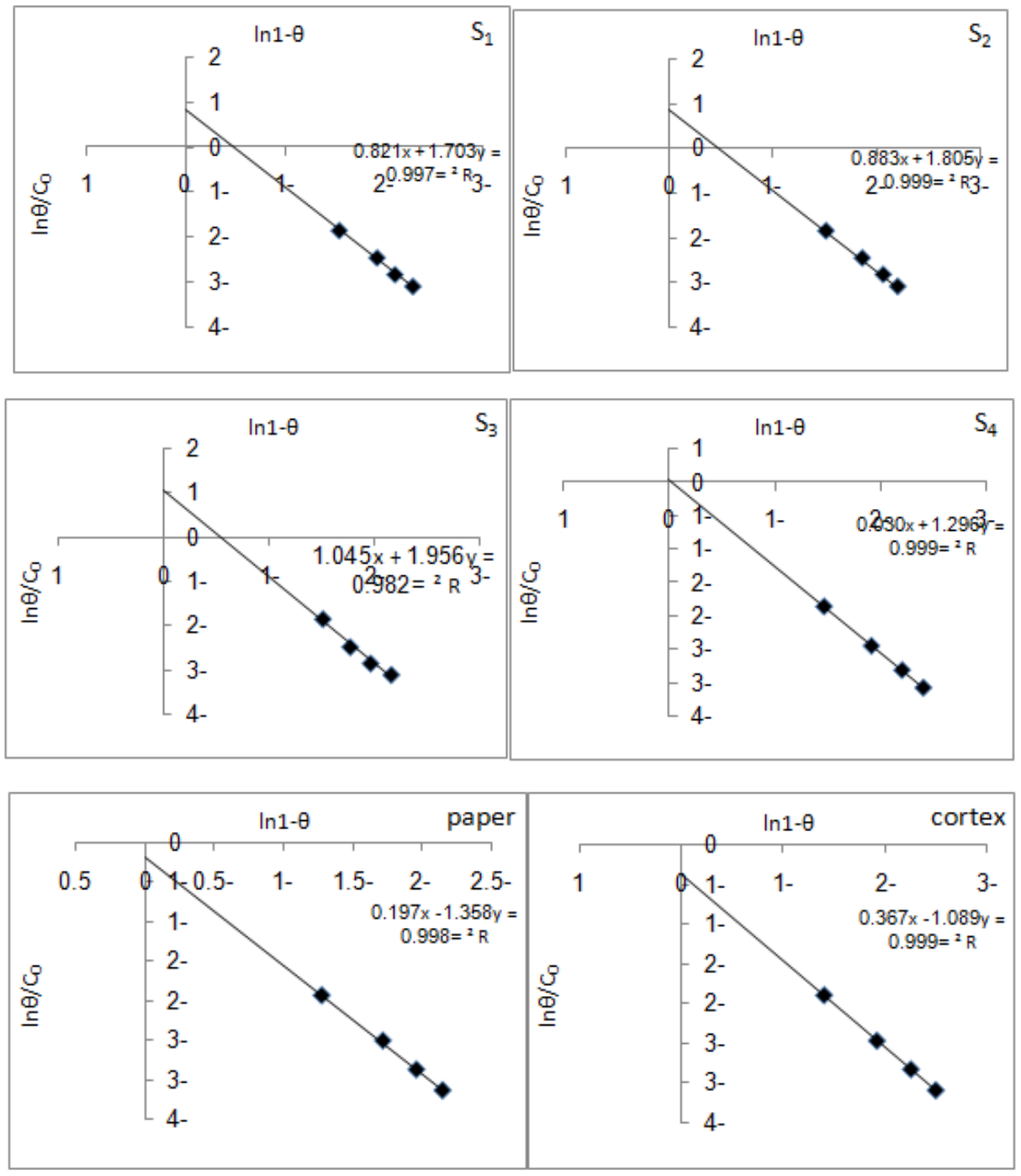

Figure8. Flory-Huggins isotherm of biureton soils, paper of plant, and cortex of plant

Table2. Values of isotherm constants for the adsorption of biuret onto soils, paper of plant, and cortex of plant

\begin{tabular}{|c|c|c|c|c|c|c|c|}
\hline models & parameters & $\mathrm{S}_{1}$ & $\mathrm{~S}_{2}$ & $\mathrm{~S}_{3}$ & $\mathrm{~S}_{4}$ & paper & cortex \\
\hline \multirow[t]{3}{*}{ Frandlich } & $\mathrm{K}_{\mathrm{F}}$ & 1.7396 & 1.6546 & 1.6380 & 1.4445 & 1.1200 & 1.0889 \\
\hline & $\mathrm{n}$ & 0.4305 & 0.4557 & 0.5044 & 0.2882 & 0.3251 & 0.1892 \\
\hline & $\mathrm{R}^{2}$ & 0.9966 & 0.9997 & 0.9873 & 0.9984 & 0.9988 & 0.9901 \\
\hline \multirow[t]{3}{*}{ Langmuir } & $\mathrm{K}_{1}$ & 0.3802 & 0.3375 & 0.2964 & 0.4830 & 0.3632 & 0.5582 \\
\hline & $\mathrm{C}_{\mathrm{m}}$ & 6.2774 & 6.9444 & 8.0710 & 3.1867 & 3.6995 & 1.7497 \\
\hline & $\mathrm{R}^{2}$ & 0.9378 & 0.9429 & 0.9968 & 0.9738 & 0.9369 & 0.9925 \\
\hline \multirow[t]{3}{*}{ Harkin-Jura } & $\mathrm{A}$ & 4.5662 & 10.8577 & 11.5207 & 6.6934 & 6.8728 & 4.1858 \\
\hline & B & 0.2808 & 0.7318 & 0.8076 & 0.5535 & 0.8054 & 0.4847 \\
\hline & $\mathrm{R}^{2}$ & 0.8806 & 0.8856 & 0.9476 & 0.9156 & 0.8744 & 0.9460 \\
\hline \multirow[t]{3}{*}{ Halsey } & $\mathrm{K}_{\mathrm{H}}$ & 1.7312 & 1.6963 & 1.7741 & 1.2764 & 1.0886 & 1.0378 \\
\hline & $\mathrm{n}$ & 0.4305 & 0.4557 & 0.5044 & 0.2882 & 0.3251 & 0.1892 \\
\hline & $\mathrm{R}^{2}$ & 0.9966 & 0.9997 & 0.9873 & 0.9984 & 0.9988 & 0.9901 \\
\hline \multirow[t]{3}{*}{ Elovich } & $\mathrm{K}_{\mathrm{E}}$ & 0.1945 & 0.1780 & 0.1637 & 0.2083 & 0.1541 & 0.2136 \\
\hline & $\mathrm{q}_{\mathrm{m}}$ & 16.501 & 17.123 & 18.0504 & 13.140 & 14.134 & 11.467 \\
\hline & $\mathrm{R}^{2}$ & 0.9491 & 0.9476 & 0.9885 & 0.9573 & 0.9446 & 0.9595 \\
\hline \multirow[t]{3}{*}{ Temkin } & $\mathrm{K}_{\mathrm{T}}$ & 1.1104 & 1.0648 & 1.0783 & 1.0475 & 1.25887 & 1.1594 \\
\hline & $\mathrm{B}_{\mathrm{T}}$ & 20.870 & 19.525 & 17.102 & 30.766 & 26.3810 & 45.968 \\
\hline & $\mathrm{R}^{2}$ & 0.9532 & 0.9603 & 0.8953 & 0.9361 & 0.9580 & 0.8988 \\
\hline \multirow{3}{*}{ Flory-Huggins } & $\mathrm{K}_{\mathrm{FH}}$ & 2.2745 & 2.4186 & 2.8442 & 1.0313 & 1.2188 & 1.4441 \\
\hline & $\mathrm{n}$ & 1.7036 & 1.8058 & 1.9562 & 1.2960 & 1.3580 & 1.0892 \\
\hline & $\mathrm{R}^{2}$ & 0.9971 & 0.9996 & 0.9821 & 0.9999 & 0.9989 & 0.9999 \\
\hline
\end{tabular}


Equations Adsorption Isotherms for Biuret on Soils, Paper and Cortex Plant Application of the Freundlich, Langmuir, Temkin, Elovich, Flory-Huggins, Halsey, and Harkins-Jura

\subsection{Thermodynamic Study}

To investigate the thermodynamic nature of soils for biuret, different standard parameters $\Delta \mathrm{G}^{\circ}$ (Gibbs free energy), $\Delta H^{\circ}$ (enthalpy) and $\Delta \mathrm{S}^{\circ}$ (entropy) have been calculatedusing the equations

$\Delta \mathrm{H}^{0}-\mathrm{T} \Delta \mathrm{S}^{0}=-\mathrm{RT} \ln \mathrm{K}_{\mathrm{c}}$

$\mathrm{R} \ln \mathrm{K}_{\mathrm{c}}=\Delta \mathrm{S}^{0}-\frac{\Delta \mathrm{H}^{0}}{\mathrm{~T}}$

Where $\mathrm{Kc}$ is the distribution coefficient constant for adsorption, $\mathrm{R}$ is the gas constant $(\mathrm{KJ} / \mathrm{mol} / \mathrm{K})$ and $\mathrm{T}$ is the absolute temperature (Kelvin). Based on the Van't Hoff plot of $\ln \mathrm{K}_{\mathrm{c}}$ verses $1 / \mathrm{T}$, the values of $\Delta \mathrm{H}^{\circ}$ oand $\Delta \mathrm{S}^{\circ}$ were determined from the slope and intercept respectively Figure (9) [24].

The determination of the thermodynamic parameters $\left(\Delta \mathrm{H}^{\mathrm{o}}, \Delta \mathrm{S}^{\mathrm{o}}\right.$ and $\left.\Delta \mathrm{G}^{\circ}\right)$ for biuret as given in (Table 3) can provide mechanism insights into biuret adsorption onto soils, paper and cortex plant. The values of the standard enthalpy change $\left(\Delta \mathrm{H}^{\circ}\right)$ were positive in the (soils, paper and cortex plant), indicating that it is an endothermic process for biuret adsorption onto sols.

The values of the Gibbs free energy change $\left(\Delta G^{o}\right)$ were all negative at two temperatures studied herein as expected for a spontaneous process under our experimental conditions. The higher the reaction temperature, the morenegative the value of $\Delta \mathrm{G}^{\mathrm{o}}$, indicating that the adsorption reaction is more favorable at elevated temperatures [25].

However, the values of the standard entropy change $\left(\Delta S^{o}\right)$ in soils were all positive for biuret sorption onto soils, which indicates that during the whole adsorption process, some structural changes occurs on soils surface and thus leading to an increase in the disorderness at the soil- water interface. In addition, whether or not a surface adsorption reaction is an associative or dissociative mechanism, strongly depends on the value of $\Delta \mathrm{S}^{\mathrm{o}}$. When the value of $\Delta \mathrm{S}^{\mathrm{o}}$ is higher than $-10 \mathrm{~J} / \mathrm{K} \mathrm{mol}^{-1}$, a dissociative mechanism controls adsorption [25].

The higher values obtained for $\Delta \mathrm{S}^{\circ}$ in agricultural soil than in undisturbed soil confirmed that agricultural soil has comparatively low sorption capacity for biuret which leads to less $\mathrm{k}_{\mathrm{c}}[26]$.

Table3. Values of $\left(\Delta G^{\circ}, \Delta H^{\circ}\right.$ and $\left.\Delta S^{\circ}\right)$ for the adsorption of biuret onto soils, paper of plant, and cortex of plant

\begin{tabular}{|l|l|l|l|l|l|c|}
\hline & \multicolumn{1}{|c|}{$\mathrm{T} 1$} & \multicolumn{1}{|c|}{$\mathrm{T} 2$} & \multicolumn{1}{c|}{$\mathrm{T} 3$} & $\Delta \mathrm{H}^{\circ} \mathrm{kJ} / \mathrm{mol}$ & $\Delta \mathrm{S}^{\circ} \mathrm{J} / \mathrm{K} \mathrm{mol}$ & $\mathrm{R}^{2}$ \\
\cline { 2 - 4 } Sample & $\Delta \mathrm{G}^{\circ} \mathrm{KJ} / \mathrm{mol}$ & $\Delta \mathrm{G}^{\circ} \mathrm{KJ} / \mathrm{mol}$ & $\Delta \mathrm{G}^{\circ} \mathrm{KJ} / \mathrm{mol}$ & & & \\
\hline $\mathrm{S}_{1}$ & -232.428 & -349.159 & -452.183 & 3041.3 & -10.988 & 0.9987 \\
\hline $\mathrm{S}_{2}$ & -261.082 & -235.255 & -690.531 & 6221.1 & -21.472 & 0.7050 \\
\hline $\mathrm{S}_{3}$ & -292.328 & -600.487 & -671.568 & 5321.7 & -18.962 & 0.8847 \\
\hline $\mathrm{S}_{4}$ & -174.915 & -747.740 & -809.579 & 9201.2 & -31.733 & 0.8223 \\
\hline paper & -243.438 & -299.239 & -240.191 & 310.98 & 0.16230 & 0.8024 \\
\hline cortex & -140.156 & -156.935 & -94.9740 & 826.83 & -2.2591 & 0.8969 \\
\hline
\end{tabular}

\section{Conclusions}

The results derived from this work indicate that the thermodynamic parameters are related to both the nature of sorbate and the nature of solid particles. The thermodynamic analysis of biuret adsorption indicates that the

surface reaction of biuret adsorption onto soils is an endothermic and spontaneous process. Results of thermodynamic studies revealed that biuret sorption reaction in soils, paper and cortex were less susceptible to biuret toxicity due to obtaining high $\mathrm{k}_{\mathrm{d}}$ values at high temperature $\left(45^{\circ} \mathrm{C}\right)$. But at ambient temperature $\left(25^{\circ} \mathrm{C}\right)$, agricultural soils were more prone to biuret toxicity than undisturbed soil indicating that such soils will pose more problems of biuret contamination and its toxicity to the plants. Thus soil properties, nature of pollutant and soil environment particularly temperature needs to be considered in the assessment of soil quality. The negative values obtained for $\Delta S^{0}$ in agricultural soil also confirmed that agricultural soil has high sorption capacity due to high degree of order at solid-solutioninterface during the sorption of biuret. The findings in this study are quite important to understand the physicochemical behavior of the interested radionuclides in the natural environment. The experimental adsorption data was fitted according to the following order: Freundlich $=$ Halsely $>$ Flory-Huggins $>$ Langmuir $>$ Elovich $>$ Temkin $>$ Harkin-Jura isotherm models. 
Equations Adsorption Isotherms for Biuret on Soils, Paper and Cortex Plant Application of the Freundlich, Langmuir, Temkin, Elovich, Flory-Huggins, Halsey, and Harkins-Jura

\section{REFERENCES}

[1] Panida Sampranpiboon, Pisit Charnkeitkong, and Xianshe Feng, Equilibrium Isotherm Models for Adsorption of Zinc (II) ion from Aqueous Solution on Pulp Waste, Wseas Transactions on Environment and Development, Volume 10(2014) 35-47.

[2] K.Y. Foo, and B.H. Hameed, An overview of landfill leachate treatment via activated carbon adsorption process, J. Hazard. Mater, (2009) 54-60.

[3] Thompson, G., Swain, J., Kay, M.. Forster, and C.F., The treatment of pulp and paper mill effluent: A review. Bioresour. Technol. 77(2001) 275-286.

[4] Jianming Xue, Roger Sands, and Peter W. Clinton, Effect of biuret on growth and nutrition of Douglas-fir (Pseudotsuga menziesii (Mirb) Franco) seedlings, Forest Ecology and Management, Volume; 192(2004) 335-348.

[5] Pusino, A., Pinna, V. M. and Gessa, C., Azimsulfuron Sorption-desorption on Soil. J. Agr. Food Chem., 52(2004) 3462-3466.

[6] R.L. Mikkelsen, By R.L. Mikkelsen, Biuret in Urea Fertilizers, Better Crops/Vol. 91(3) (2007).

[7] M. Rounak Shariff., "Compost Adsorption Desorption of Picloram in the Presence of Surfactant on Six Agricultural Soils". International Journal of Scientific \& Engineering Research, 2(5)( 2011) 22295518.

[8] M. E. Sanchez, R. Mendez, X. Gomez, and J. Martin-Villacorta., Determination of diazinon and Fenitrothion in the environmental water and soil samples by HPLC. Journal of liquid chromatography \& related technologies. Vol. 26(3) (2003) 483-497.

[9] M. Rounak Shariff and M. Kafia Shareef, "Thermodynamic Adsorption of Herbicides on eight Agricultural Soils". International Journal of Scientific \& Engineering Research Volume 2(6) (2011) 238245.

[10] M. B. Ibrahim, and S. Sani, Comparative Isotherms Studies on Adsorptive Removal of Congo Red from Wastewater by Watermelon Rinds and Neem-Tree Leaves, Open Journal of Physical Chemistry, volume: 4(2014) 139-146.

[11] M. Rounak Shariff., "Effect of Co-pesticide on adsorption -Desorption Process on Agricultural Soils". International Journal of Engineering Research and Development. Volume:1(2) (2012) 55-69.

[12] MarceloKogan, Alejandia Metz and Rodrigo Ortega., "Adsorption of glyphosate in chilecan and its relationship with unoccupied phosphaste binding sites". Pesqagropes bras .Brasilia., vol 38(4) ( 2003) 513519.

[13] Adlophe Monkiedje and Micheal Spiteller., "fungicides, mefenoxam and metalaxly, and their acid metabolite in typical Cameroonian and German soils". chemosphere., vol. 49(6) (2002) 659-668.

[14] Mehdi Rahimi, Mehdi Vadi, Langmuir, Freundlich and Temkin Adsorption Isotherms of Propranolol on Multi-Wall Carbon Nanotube, J. of Modern Drug Discovery And Drug Delivery Research, (2014) 1-3.

[15] U. John, Kennedy oubagaranadin, N. Sathyamuthy, Evaluation of Fuller's earth for the adsorption of mercury from aqueous solutions: A comparative study with actived carbon, Journal of Hazardous Materialsvolume:142(2007) 165-174.

[16] S.Y. Elovich, O.G. Larinov, Theory of adsorption from solutions of nonelectrolytes on solid (I) equation adsorption from solutions and the analysis of its simplest form, (II) verification of the equation of adsorption isotherm from solutions, Izv. Akad.Nauk. SSSR, Otd. Khim. Nauk, volume: 2 (1962) 209-216.

[17] Hardiljeet K. Boparai, Meera Joseph, and Denis M. O'Carroll, Kinetics and thermodynamics of cadmium ion removal by adsorption onto nano zerovalent iron particles, Journal of Hazardous Materials, volume: 186 (2011) 458-465

[18] Muhammad Tahir Amin, Abdulrahman Ali Alazba and Muhammad Shafiq, Adsorptive Removal of Reactive Black 5 from Wastewater Using Bentonite Clay: Isotherms, Kinetics and Thermodynamics, Sustainability, volume: 7(2015) 15302-15318.

[19] S.Brunauer, P. H. Emmet, E. Teller, "Adsorption of gases in multi molecular layers, J. Am. Chem. . . . Soc., Vol. 60(2) (1938) 309-319.

[20] Abdullah, N.M., Othaman, R., Abdullah, I., Jon, N. and Baharum, A., Studies on the Adsorption of Phenol Red Dye Using Silica-Filled enr/pvc Beads. Journal of Emerging Trends in Engineering and Applied Sciences, Vol,3 ((2012) 845-850.

[21] Liu, J. and Wang, X., Novel Silica-Based Hybrid Adsorbents: Lead(II) Adsorption Isotherms. The Scientific World Journal,, Article ID: (2013) 897159.

[22] Basar, C.A., "Applicability of the Various Adsorption Models of Three Dyes Adsorption onto Activated Carbon Prepared from Waste Apricot”. J. of Hazard Mater. B135: (2006) 232-241. 
Equations Adsorption Isotherms for Biuret on Soils, Paper and Cortex Plant Application of the Freundlich, Langmuir, Temkin, Elovich, Flory-Huggins, Halsey, and Harkins-Jura

[23] Wankasi, D. Tarawou, and T, Studies on the Effect $\mathrm{pH}$ on the Sorption of $\mathrm{Pb}$ (II) and $\mathrm{Cu}$ (II) ions from Aqueous Media by Nipa Palm (Nypa fruticans Wurmb) J. Appl. Sci. Environ. Manage. December, Vol. 12(4) (2008) $87-94$.

[24] Melvin Samuel S, Evy Alice Abigail M, Ramalingam Chidambaram, Isotherm Modelling, Kinetic Study and Optimization of Batch Parameters Using Response Surface Methodology for Effective Removal of Cr(VI) Using Fungal Biomass, journal. pone, (2015) 1-15.

[25] Hu BW, Cheng W, Zhang H, Yang ST, Solution chemistry effects on sorption behavior of radionuclide $\mathrm{Ni}(\mathrm{II})$ in illite-water suspensions. J Nucl Mater, 406 (2010) 263-270.

[26] Yang S, Li J, Shao D, Hu J, Wang X, Adsorption of Ni (II) on oxidized multi-walled carbon nanotubes: effect of contact time, pH, foreign ions and PAA. J Hazard Mater,166 (2009) 109-116.

Citation: Layla Balasem Almalike, "Equations Adsorption Isotherms for Biuret on Soils, Paper and Cortex Plantapplication of the Freundlich, Langmuir, Temkin, Elovich, Flory-Huggins, Halsey, and Harkins-Jura”, International Journal of Advanced Research in Chemical Science (IJARCS), vol. 4, no. 5, p. 9-20, 2017. http://dx.doi.org/10.20431/2349-0403.0405002

Copyright: (C) 2017 Authors. This is an open-access article distributed under the terms of the Creative Commons Attribution License, which permits unrestricted use, distribution, and reproduction in any medium, provided the original author and source are credited. 